\title{
An ancient Caria Village: Çomakdağ Kızılağaç in Mylasa, Turkey
}

\author{
Mehmet Turgut ${ }^{1,2}$
}

Received: 23 June 2018 / Accepted: 29 June 2018 / Published online: 11 July 2018

(C) Springer-Verlag GmbH Germany, part of Springer Nature 2018

Unsurprisingly, the foundations for human neurodevelopment are laid down in early childhood period. In addition to the dynamics of development of the kids, an evaluation of social and ancient historical bases of their families is important for pediatric neurologists and neurosurgeons, as did in the following example.

\section{Geography of Çomakdağ Kızılağaç, an ancient Caria Village}

Çomakdağ villages, Kızılağaç, İkiztaş, and Ketendere, nestled the foothills of the Latmos Mountains (Beşparmak Dağları) in ancient Caria territory in the western Anatolia, attract attention with its wedding ceremonies, folk costumes, and stone houses at the higher altitudes (Fig. 1, left). Interestingly, they have preserved unique culture and architecture until today. Colorful flowers on the edges of traditional silk scarves of the peasant women, called "çemperi," and 25-35 yellow Ottoman liras on their fronts are shining [1] (Fig. 1, right). The gulf of Latmos in Herakleia on which the brightness and clearness of the Moon Goddess of Selene has reflected and where the Goddess had lived is near to their villages. The flowers that the women place on their heads are in perfect harmony with the houses of Çomakdağ villages. Nomadic women adorned with gold in Çomakdağ villages reminded the following mythological story.

\section{Mehmet Turgut}

drmturgut@yahoo.com

1 Department of Neurosurgery, Adnan Menderes University School of Medicine, 09100 Aydın, Turkey

2 Cumhuriyet Mahallesi, Adnan Menderes Bulvarı, Haltur Apartmanı, No:6/7, 09020 Efeler/Aydın, Turkey

\section{Hecatomnus of Mylasa and Labraunda in ancient Caria}

Mylasa (now Milas) was the first capital of the Caria (Fig. 2) (https://en.wikipedia.org/wiki/Caria); Carians, a fighter and sailor tribe of Anatolia, had worshipped Zeus Labrandios, the God of the Gods with doubleaxe, and Idreus, son of Hecatomnus, built a temple for the sake of Zeus in Labraunda, a location very close to Çomakdağ villages (https://en.wikipedia.org/wiki/ Hecatomnus). Hecatomnus of Mylasa, the satrap of Caria for the Persian king Artaxerxes II (404-358 BC) between 392 and 377 BC, was appointed Persian official in western Anatolia (https://en.wikipedia.org/ wiki/Hecatomnus) (Fig. 3) [2].

\section{Fishes with golden earring and neckplaces in Zeus Labrandios temple}

Roman author Aelian specifies oracle eels in Labraunda in his book "Nature of Animals" based on information from the encyclopedia of Plinius [2-4]. Aelian notes that eels living in holy pool located in an area below Labrandios Temple are adorned with golden earrings and necklaces [2-4]. These fishes, dedicated to Zeus Labrandios, are blessed, in one sense; they are characterized as oracle fishes since diviners are foretelling only by means of them [2-4]. According to author, foretelling related to future of individuals was being assessed according to behaviors of fishes: if fishes eat the food given by the person having a wish, then it was believed that the wish would become real otherwise some challenges would be faced [2-4]. According to some ancient sources, desperate people seeking healing for various health problems such as infertile couples even from distant Caria cities who wanted to have children and probably those having sick children have 
Fig. 1 A photograph of Kızılağaç Village, center of Çomakdağ villages in ancient Caria territory, which is the place of birth of the author (left). A photograph of the peasant women, who is the mother at the age of 80 years of the author and lives in Çomakdağ Kızılağaç, with shining yellow Ottoman liras on her front and golden neckplace, in addition to wonderful red rose on the traditional silk scarf (right)

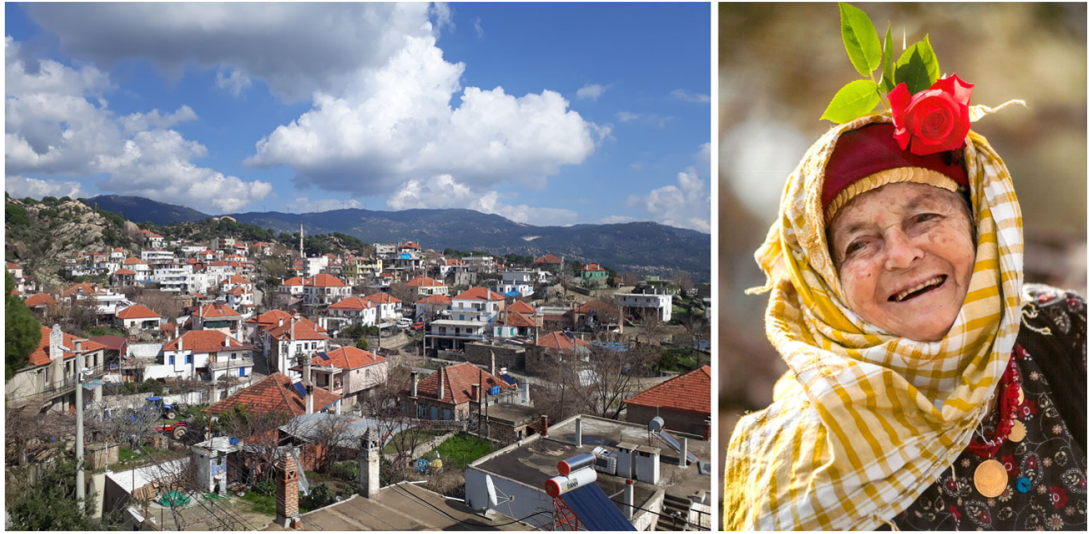

started visiting this temple to offer gifts and sacrifices [2-5]. Thus, the reputation of the temple was spreading and becoming a healer sacred area in turn among the
Carians [2, 5]. According to Plinius, Greeks and Romans believed that eels are genderless and deem as holy [2-5].

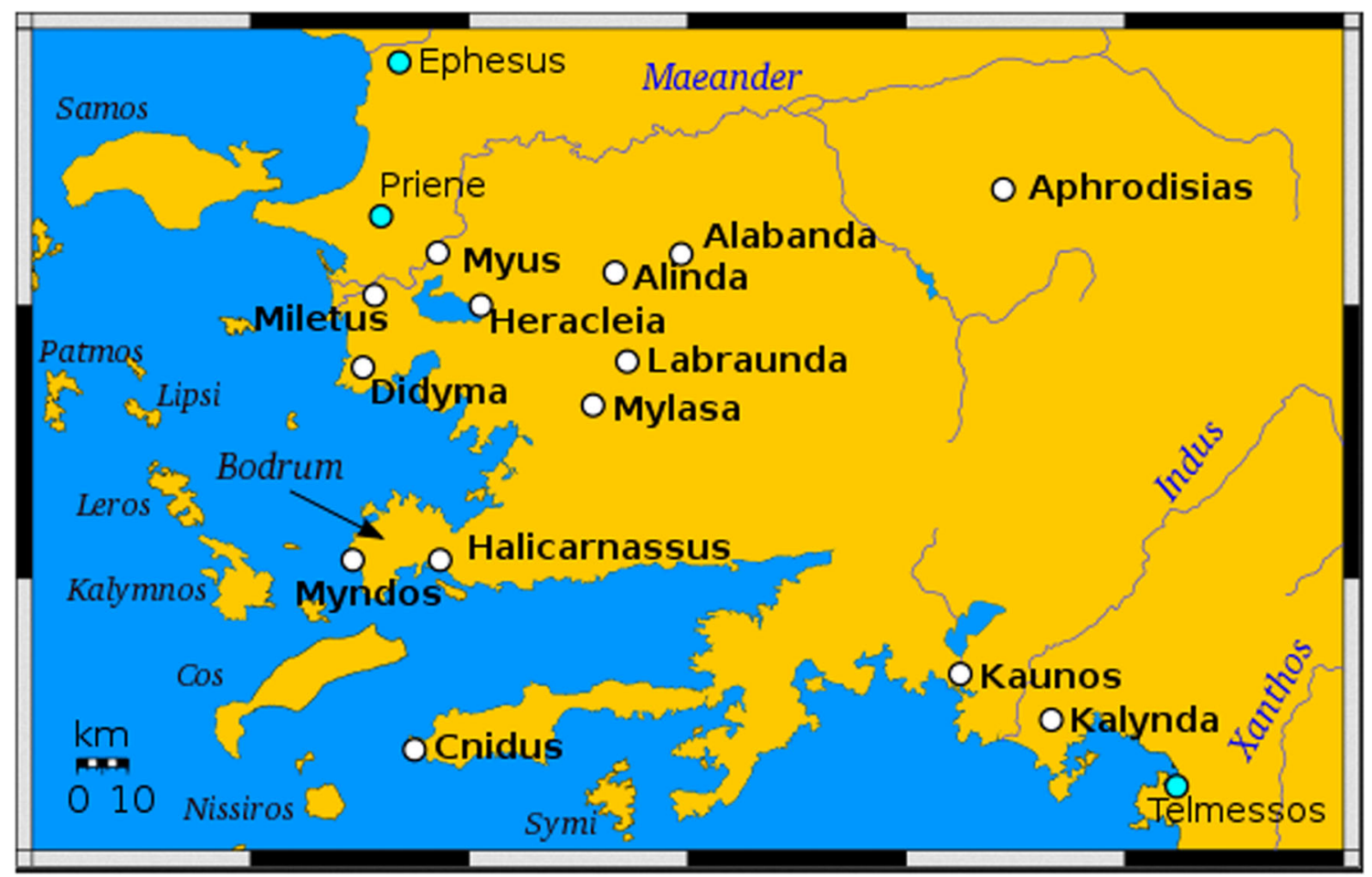

Fig. 2 A map showing the ancient cities, including Labraunda and Mylasa near today Çomakdağ villages, in Caria (from https://en.wikipedia.org/wiki/ Caria) 


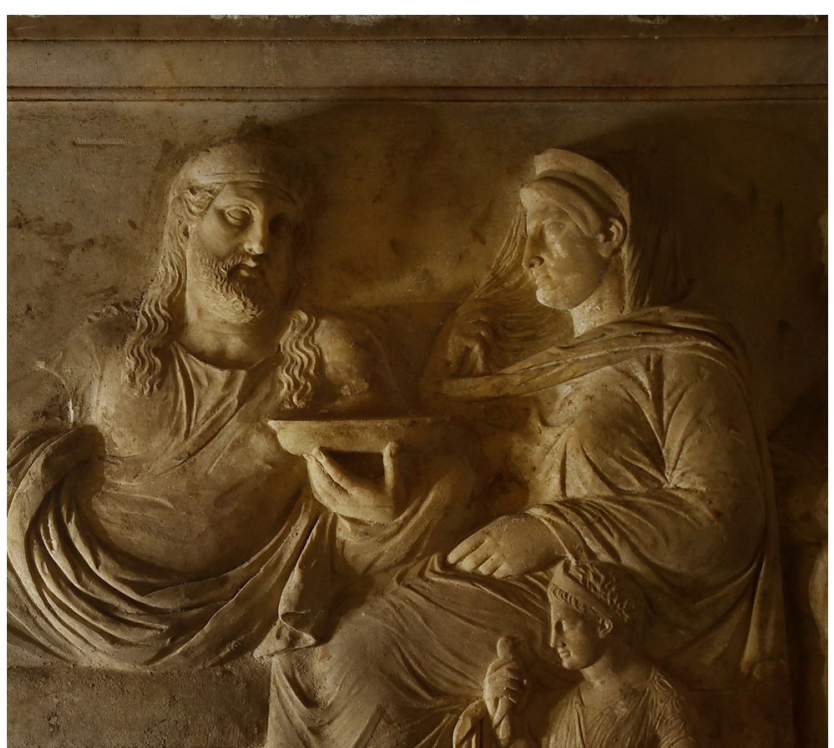

Fig. 3 A unique view of Hecatomnus tomb in Uzunyuva, Mylasa, was built 2400 years ago (from the private collection of archeologists Abuzer Kızıl and Fahri Ișı, supported by the Culture and Tourism Ministry)

\section{Cloth toy dolls simulating cultural features in Çomakdağ villages}

Interestingly, each of the eels attached with gold jewelry has become women in the "gold-silk-flower" triad, the most important sacred symbols of the women in Çomakdağ villages, in our age. Today, women in these villages continue to make nice "cloth toy dolls" with golden neckplaces reflecting their unique cultural features for their children, despite the popularity of fabricmade toys in the world (Fig. 4 and cover). Thanks to these colorful villages and their friendly, hospitable people.

Today, it seems that strong, resilient, and daring features of the people living in current Çomakdağ nomad villages root back to Carians. Now, it is believed that the tradition of wearing gold necklaces in the necks of girls living in Çomakdağ Kızılağaç today inherited from the eel believed to cure the ancient Carian children in the mythological story.

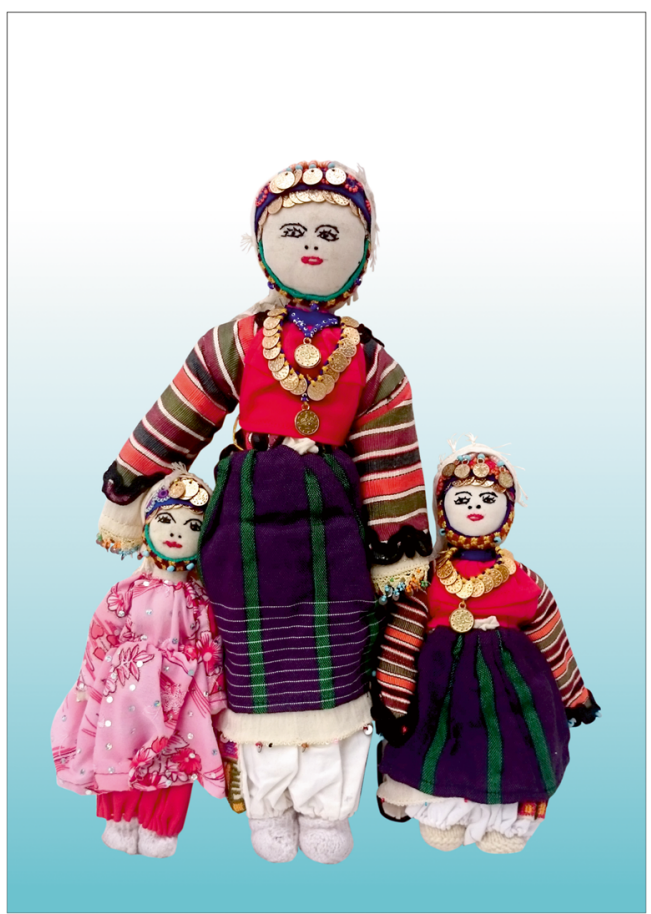

Fig. 4 and cover A photograph (also used as cover picture) of cloth toy dolls (mother and her girls) handmade in Çomakdağ villages, illustrating traditional costumes of the women, reminding the mytological eels with golden neckplaces of Aelian in Labraunda, Caria (right)

\section{Compliance with ethical standards}

Conflict of interest The author has no conflicts of interest.

\section{References}

1. Özdemir M (2012) Traditional women costume in Comakdağ Village of Milas a Province (in Turkish). Millî Folklor 24:345-355

2. Küçükeren CC (2007) Legends of Caria (in Turkish). Ekin Publishing Group, İstanbul

3. Aelianus C, Scholfield AF (1958) On the characteristics of animals. Harvard University Press, Cambridge

4. Pliny P, Andrews AC, Eichholz DE, Jones WHS, Rackham H (2014) Natural history. Harvard University Press, Cambridge

5. Tate K (2005) Sacred places of goddess: 108 destinations. CCC Publishing, San Francisco 